\title{
Tower Planning and Arrangements Mobile Telecommunication District Central Aceh With Fuzzy Clustering Method
}

\author{
Eva Safwani ${ }^{1}$, Ahmad Firdausi ${ }^{2}$, Galang P. N. Hakim ${ }^{3}$ \\ 1,2,3 Department of Electrical and Engineering, Faculty of Engineering, Universitas Mercu Buana, Jakarta \\ Email: evajafar77@gmail.com, ahmad.firdausi@mercubuana.ac.id,galang.persada@mercubuana.ac.id
}

\begin{abstract}
Advances in technology, especially in the telecommunications industry has been progress rapidly. Various types of cellular communication systems began operating by covering targeted service areas throughout Indonesia even to the corners of the archipelago, operators continue to try to build infrastructure so that service and the quality is increasing. One of the on going infrastructure developments is Base Transceiver Station (BTS). However, BTS development infrastructure must consider the aesthetics and compliance with the Regional Spatial Plan an area to determine the potential location of tower construction optimally. In this paper we propose the Fuzzy Clustering and Harmony Search to optimize the placement of potential new tower locations. In the optimization process using several parameters such as total population, total area, and shared tower needs for the future 5 (five) years. The results of optimization show that needs BTS in 2024 network services require an additional 74 BTS and supported by 21 new towers together. Where each zone is able to cover 2 new towers at once, so 21 new tower points can be represented using 10 zones. In addition to the regional spatial layout, potential points can also be determined using the center point cluster through method Fuzzy C-Means. After that the new tower point can be optimized using the method Harmony Search by minimizing function path loss.
\end{abstract}

Keywords - Cluster, Fuzzy, Telecommunication Tower, Optimization.

\section{INTRODUCTION}

Nowadays in present the technological advances and the telecommunications industry has been progress rapidly. Various types of communication systems already operating by covering areas throughout Indonesia such as VSAT [1], microwave links [2], and many others. The availability of telecommunications services is sought by number of operators. For an adequate telecommunication service we need sufficient tower for antenna placement of Base Transceiver Station which is the main gateway for customer access [3]-[6].

It can't be denied, the addition Base Transceiver Station is a solution that gives good results in increasing the radius of coverage of a provider [7], [8]. Therefore, the thing that must be done is to make a plan in terms of the placement of towers with cellular telecommunications by taking into account environmental aesthetics and spatial planning. Then, determine the coverage area for Central Aceh Regency in order to meet the needs of the Base Transceiver Station by taking into account the traffic capacity that will be served by each cell. A lot of methods that has been used for tower planning such as area planning using Differential Evolution algorithm [9], [10], topography planning [11], Topsis for Tower attribute, and human population prediction, Fuzzy CMeans [12], [13] and others.

If viewed from the opposite point of view, Central Aceh District is a Province in Aceh that is still having difficulty accessing cellular telecommunications networks due to the lack of availability of telecommunications towers in the Regency. Each sub-district only has two or three telecommunication towers, and there are even a number of villages that have not yet been accessed by cellular networks. The increase in the number of tower locations is very supportive for the achievement of community needs for telecommunications services. But on the other hand, the placement of telecommunication towers without proper planning will have an adverse effect. Coordination of the construction of the tower between the operator and the Regional Government, the scenery in the area will be filled with BTS (Base Transceiver Station) which is disturbing and not harmonious. Based on the problems that have been explained above, then this can be resolved by compiling a complete and detailed master plan on the arrangement of tower locations in the Central Aceh District. The tower planning master plan needs to refer to the actual conditions of meeting the needs of the community telecommunications, aesthetics, and security for the community, the plan needs to pay attention to the conditions of environmental regulation in the Central Aceh Regency. Central Aceh District produces one of the best types of Arabica coffee in the world. For planning and structuring Base Transceiver Station specifications. The optimization process takes into account the area of Central Aceh Regency, pays attention to environmental aesthetics, spatial planning determines coverage area, considers the traffic capacity that will be served by each cell, population growth, growth in number of 
customers, one of the methods used to obtain the location of telecommunications towers. Optimal is to use the Fuzzy Clustering method which is supported by using the Harmony Search algorithm and the digital map used is Map Info.

\section{DATA COLlection \& PROCESSING}

In this section, data collection was needed to indicate the need of new bts infrastructure. Meanwhile data processing was needed to validate and show the needed quantity of bts infrastructure. Figure 1 show the research flowchart.

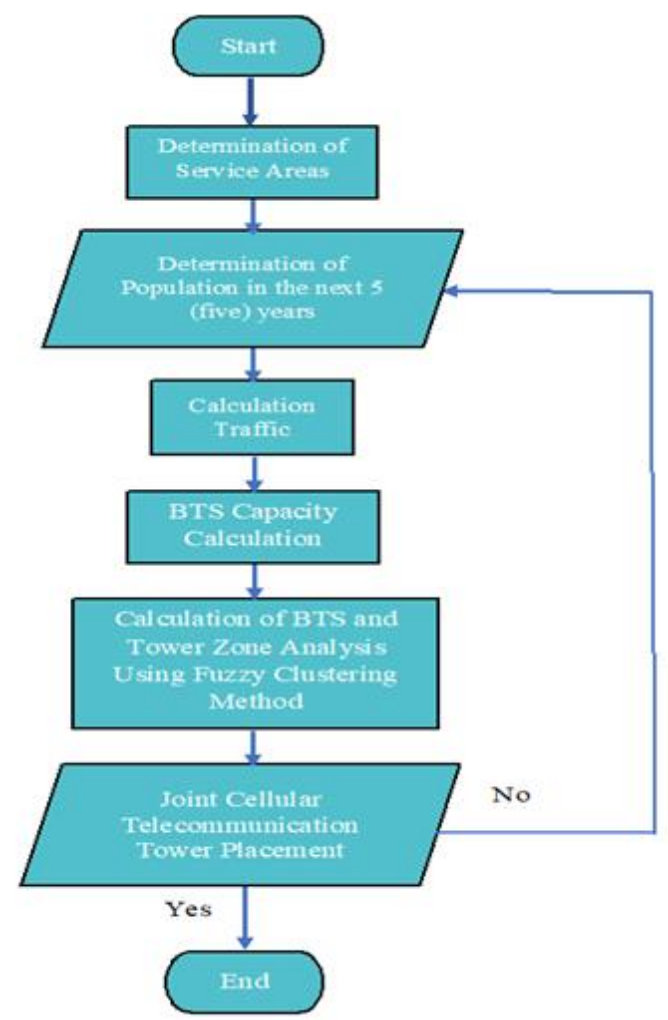

Fig. 1. Flow Chart of a Simulated Tower Tower Planning and Placement From the picture above, first select the service area by determining the population of the future five (5) years. Then calculate the traffic, calculate the capacity of base stations, the number of base stations and tower zone analysis using the fuzzy clustering method and the placement of shared telecommunication towers. If conditions are not accepted, then it will return to the determination of the population of the future five (5) years.

\section{A. Data collection}

The data used as references include the coordinates of the existing tower, tower height, number of BTS, antenna height of each sectoral antenna and cellular operators using the existing tower. Population data were obtained from the Central Aceh District Statistics 2012, 2015, and 2018 from the Central Statistics Agency. The digital map used is a map of Central Aceh District based on MapInfo. This map was obtained from the National Survey and Mapping Coordinating Board. Map of Central Aceh District is presented in several layers, one layer with another layer distinguished by color.

\section{B. Data Processing and Analysis}

Calculation of BTS needs to be carried out is for the next five years, that is until 2024. Some of the parameters used in the calculation of the planning needs for the number of BTS are as follows:

- Prediction of the population of sub distric in center aceh such as Atu Lintang, for the next 5 (five) years we can use equation [8]:

$$
\begin{aligned}
& P_{t}=P_{0}(1+r)^{t} \\
& \text { P_2024=6794 }(1+0.023)^{5} \\
& \text { P_2024=7612 person }
\end{aligned}
$$

Where:

$P_{t}=$ total population of the year $\mathrm{t}$

$P_{0}=$ initial population

$r=$ the population growth rate

$t=$ number of years from 0 to $\mathrm{t}$

- The density of cellular users for the Sumatra region is assumed to be the same as the density of cellular users in Central Aceh District, which is $70.85 \%$. Based on forecasting of the population in the previous sub-chapter. Then the number of cellular users in the Atu Lintang District can be calculated using [8]:

$$
\begin{aligned}
& P=x \% P_{t} \\
& \mathrm{P}=70.85 \% \times 7612 \\
& \mathrm{P}=5393 \text { customers }
\end{aligned}
$$

Where:

$P \quad=$ total of mobile users

$x \%=$ cellular teledence $(\%)$

$P_{t}=$ total population $\mathrm{t}$ years

- The average length of cellular calls for rural areas, the average length of cellular calls is 45 minutes / day [5]. So the traffic intensity generated by each cellular subscriber can be calculated using Traffic intensity

$$
\begin{aligned}
& \text { (A) }=45 / 24 \times 60=31.25 \mathrm{mE} \\
& A=V / T
\end{aligned}
$$

Where:

$$
\begin{aligned}
& A=\text { traffic intensity (Erlang) } \\
& V=\text { the occupation time per unit time } \\
& T=\text { the time period of observation }
\end{aligned}
$$

Example of calculating total traffic generated by cellular users for the Atu Lintang District in 2024 can be calculated:

$$
\begin{aligned}
& \mathrm{T}=5393 * 31.25 *[10) \Omega^{\wedge}(-3) \\
& \mathrm{T}=168.53125 \mathrm{E} \approx 169 \text { Erlang }
\end{aligned}
$$




$$
\mathrm{T}=\mathrm{P} * \mathrm{~A} * 10^{-3}
$$

Where:

$\mathrm{T}=$ total traffic for all mobile customers (Erlang)

$\mathrm{P}=$ total of cellular mobile customers

$\mathrm{A}=$ traffic intensity of each mobile customers (Erlang)

The maximum capacity of the UMTS radio access system can be expressed using the WCDMA chiprate value of $3.84 \mathrm{Mcps}$ and user bitrate of 144 kbps for the macrocell region. And the WCDMA system $\alpha$ values range between $50 \%-100 \%$. The $\mathrm{Eb}$ / No value used is $1 \mathrm{~dB}$ or 1.258925 . And the user activity factor, with sound activity $=2.5$ and the interference factor of 0.625 [6]

$$
\begin{aligned}
& N_{\text {sel }}=1+\frac{W / R}{\left[E_{b} / N_{0}\right]} \frac{\propto}{v[1+i]} \\
& N_{\text {sel }} \\
& =1+\frac{\left(3.84 * 10^{6}\right) /\left(144 * 10^{3}\right)}{[1.258925]} \frac{0.9}{2.5[1+0.625]} \\
& N_{\text {sel }}=30.329 \text { channel } \approx 31 \text { channel }
\end{aligned}
$$

Where:

$\mathrm{R}=$ Bitrate user (bps)

$\mathrm{W}=$ WCDMA Chiprate (Mcps)

$E_{b} /_{N_{0}}=$ Bit energy per interference $(\mathrm{dB})$

$\mathrm{v}=$ user activation factor

$\alpha=$ the power control correction factor that is Affected cell load

$\mathrm{i}=$ interference factor co-channel other cells against their own cells

Because 1 BTS consists of 3 sectors, the channel capacity in 1 BTS has 93 channels, where in the Erlang Traffic B 93 channels are equal to 81.20 Erlang. So in an area the ability of BTS to serve cellular customers can be calculated.

$$
\begin{aligned}
\text { Capacity BTS }=\frac{\text { Capacity } 1 \text { BTS }}{\text { Traffic per customer }} & =\frac{81.20 \text { Erlang }}{31.25 \text { mErlang }} \\
& =2599 \text { user } / \text { BTS }
\end{aligned}
$$

The number of BTS needed to serve cellular users is the result of the total traffic generated by cellular subscribers divided by the capacity of 1 BTS found in the area. To calculate the number of BTS needs in the Atu Lintang District in 2024, it can be used.

$B=\frac{T}{A_{B T S}}=\frac{169 \text { Erlang }}{81.20 \text { Erlang }}=2.08128 \approx 2$ BTS $[8]$

$\mathrm{B}=$ total of needed BTS

$\mathrm{T}=$ total traffic of all mobile customers $(\mathrm{E})$

$A_{B T S}=$ capacity one BTS $(\mathrm{E})$
If it is assumed that the existing tower capacity can

\begin{tabular}{|c|c|c|c|c|}
\hline No & Sub-Distric & $\begin{array}{c}\text { Population in } \\
2024\end{array}$ & total area & $\begin{array}{l}\text { needed cellular } \\
\text { tower }\end{array}$ \\
\hline 1 & Atu Lintang & 7612 & $146.27 \mathrm{~km}^{2}$ & 1 \\
\hline 2 & Bebesen & 46281 & $28.96 \mathrm{~km}^{2}$ & 4 \\
\hline 3 & Bies & 7526 & $12.32 \mathrm{~km}^{2}$ & 1 \\
\hline 4 & Bintang & 10463 & $578.26 \mathrm{~km}^{2}$ & 1 \\
\hline 5 & Celala & 9817 & $125.86 \mathrm{~km}^{2}$ & 1 \\
\hline 6 & Kebayakan & 18521 & $48.18 \mathrm{~km}^{2}$ & 2 \\
\hline 7 & Ketol & 14052 & $611.47 \mathrm{~km}^{2}$ & 1 \\
\hline 8 & Kute Panang & 8042 & $20.95 \mathrm{~km}^{2}$ & 1 \\
\hline 9 & Linge & 11499 & $1766.24 \mathrm{~km}^{2}$ & 1 \\
\hline 10 & Lut Tawar & 23691 & $83.10 \mathrm{~km}^{2}$ & 2 \\
\hline 11 & Jagong Jeget & 11509 & $188.25 \mathrm{~km}^{2}$ & 1 \\
\hline 12 & Pegasing & 20729 & $169.83 \mathrm{~km}^{2}$ & 2 \\
\hline 13 & Rusip Antara & 7541 & $599.31 \mathrm{~km}^{2}$ & 1 \\
\hline \multirow[t]{2}{*}{14} & Silih Nara & 26007 & $75.04 \mathrm{~km}^{2}$ & 2 \\
\hline & Total & 223290 & 4454,04 & 21 \\
\hline
\end{tabular}
accommodate 4 BTS, then the addition of BTS can be inserted in the tower. So the need for additional telecommunications towers in Atu Lintang District can be calculated by the equation.

$$
\begin{aligned}
& M_{2024}=\frac{\text { Number of additions BTS }}{4} \\
& M_{2024}=\frac{2}{4} \\
& M_{2024}=0.5 \approx 1 \text { tower (round up) }
\end{aligned}
$$

TABlE I. AREA And Population Versus New Cellular Tower

\section{METHODS}

Fuzzy was developed in 1965 by zadeh [14]. it was develop to find its solution using approximate reasoning, which nor very imprecise neither very precise [15], [16]. Until now a lot of new fuzzy methods has been develop not only for control [17]-[19] but also for other real world problem, such as MCDM problem [20], [21], forecasting [22], Clustering [23], risk analyst [24] and many others.

In this section we are using fuzzy algorithm to simulate and process data on table 1 using matlab as its tools. We are using Fuzzy C-Means method to be use for new BTS tower placement plan. The Fuzzy Clustering method aims to find the cluster center point so that new tower potential points can be determined. Meanwhile we need to find potential points obtained from the cluster center, therefore we need also to optimize Fuzzy C-Means results. There are several ways to optimize the Fuzzy C-Means results such as Genetic Algorithm [25], Harmony Search [26], Particle Swam Optimization [27], Multi-chain Quantum Bee Colony [28], and others. In this case, we propose to use harmony search to find optimal solution using the minimization of the path loss function. For fuzzy C-means parameter was:

- $\quad$ Cluster Num. $=2$ 
- $\quad$ Max.Iteration\# $=100$

- $\quad$ Min.Improvement $=\llbracket 10 \rrbracket^{\wedge}(-5)$

- $\quad$ Exponent $=2.0$

\section{RESULTS AND DisCUSSIONS}

The number of clusters inputted according to the data attribute is 2 (two) clusters where the number of samples is 14 sub-districts. To determine the cluster center point is done per district. An example, in Bebesen sub-district results of BTS plotting (Figure 2). Red plot is input data in the form of 10 points coordinates of the existing tower while the center point of the cluster marked by a black plot.

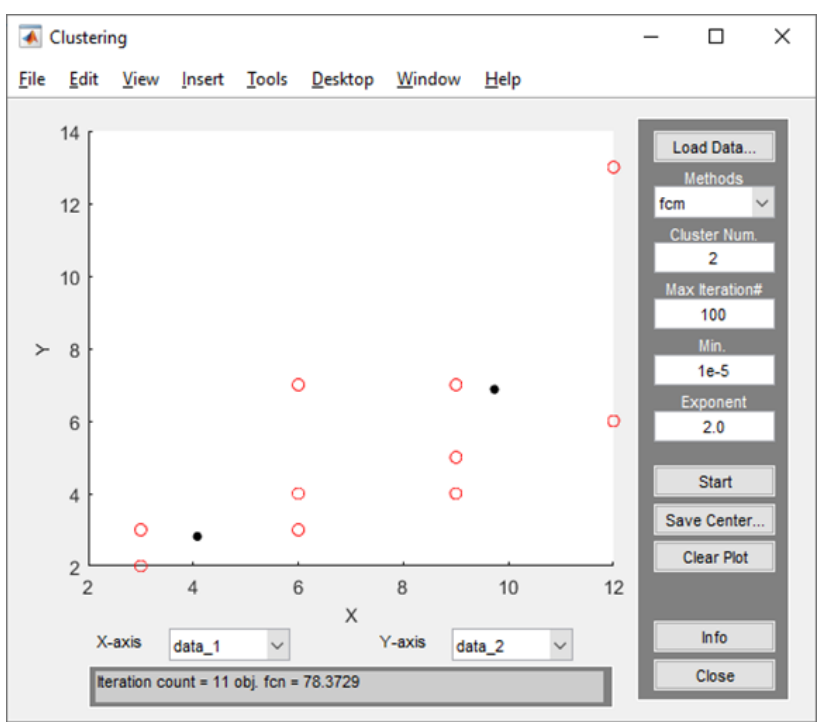

Fig. 2. Bebesen sub-district new BTS plotting

The plotting and then optimize with harmony search methods. For harmony search parameter was:

- Harmony Memory Eksisting = 7

- Harmony Memory Size (HMS) = 9

- Harmony Memory Consideration Rate (HMCR) = 0.7

- $\quad$ Pitch Adjusting Rate $(\mathrm{PAR})=0.3$

- $\quad[\mathrm{tU}, \mathrm{rU}]=[50,800]$

- $\quad[\mathrm{tL}, \mathrm{rL}]=[35,500]$

- $\quad[\mathrm{nL}, \mathrm{nU}]=[1,30]$

- $\quad$ Range tower height $(b t)=(t \mathrm{U}-\mathrm{tL}) / 100$

- $\quad$ Range radius cell $(b r)=(r U-r L) / 100$

- $\quad$ Range serial number $(b n)=(n U-n L) / 10$

The Formula was $\mathrm{tL}+$ rand $(\mathrm{tU}-\mathrm{tL})$ dan $\mathrm{rL}+$ rand $(\mathrm{rU}-$ $\mathrm{rL}$ ). Taking into account the area covered by existing towers and the results of the new tower based on simulation. We have total of 21 towers and the addition of BTS with a total of 74 BTS (Figure 3(b)). After that we plot simulation result on GIS tools such as Map Info for existing towers (Figure 3(a)) and new tower (Figure 3(b)) [29] [30].

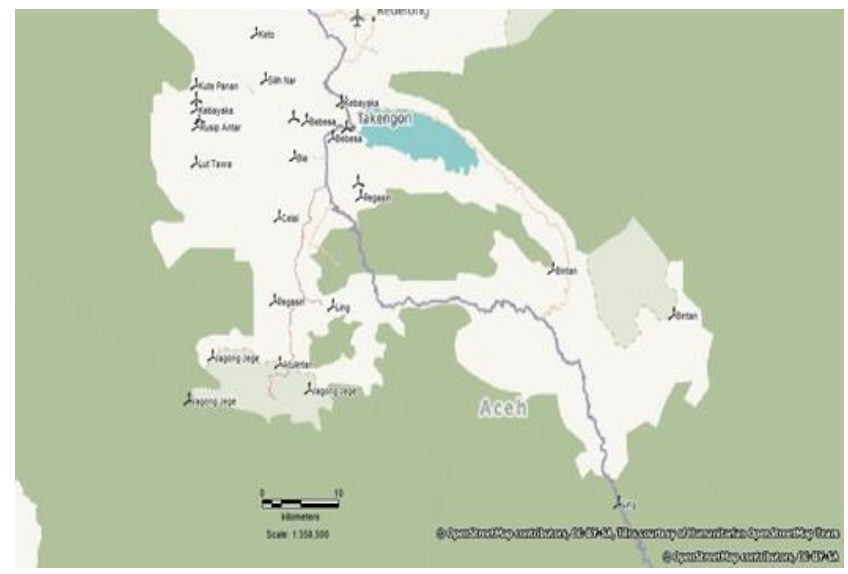

a. The placement of existing towers, 30 towers with a total of $90 \mathrm{bts}$

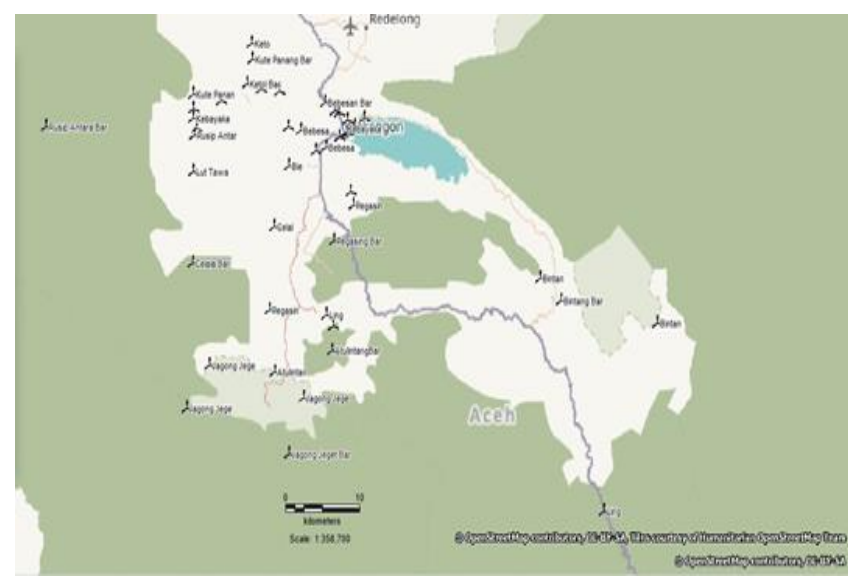

b. The placement of new tower needs in 2024 is 21 towers with the addition of $74 \mathrm{bts}$.

Fig. 3. a. The placement of existing tower zones, b new tower in mapinfo

\section{CONCLUSION}

In this paper we try to simulate the need of the new tower on middle aceh area based on human population prediction using fuzzy C-means and Harmony Search methods. From our simulation results we have additional 21 new towers, from 95 total tower in 2024 (74 existing tower). Harmony search methods also give optimization, such as service coverage of new tower zones in Central Aceh Regency within a radius range between $(600-900) \mathrm{m}$ with height of towers between $(25-50) \mathrm{m}$.

\section{REFERENCES}

[1] J. Y. C. Cheah, "Frequency reference in VSAT," IEEE Trans. Commun., vol. 42, no. 2/3/4, pp. 233-236, Feb. 1994.

[2] X. Chen and J. Yao, "A coherent microwave photonic link With digital phase noise cancellation," in Microwave Photonics (MWP) and the 2014 9th Asia-Pacific Microwave Photonics Conference (APMP) 2014 International Topical Meeting on, 2014, pp. 438441.

[3] Y. Hu, H. Dai, and B. Jiang, "Design and implementation of the Base Transceiver Station routing inspection system based on RFID," in 2010 IEEE International Conference on RFIDTechnology and Applications, 2010, no. June, pp. 81-85.

[4] W. W. Wibowo, Y. D. R. W. Astuti, and C. Hudaya, "SolarPowered Base Transceiver Station," in 2018 2nd International 
Conference on Green Energy and Applications (ICGEA), 2018, pp. $108-112$.

[5] A. Adriansyah, A. W. Dani, and K. A. Brotoatmodjo, "Power Consumption Optimization in Cooling System using Knowledge Base Temperature System," in 2018 International Conference on Electrical Engineering and Computer Science (ICECOS), 2018, vol. 17, pp. 135-140.

[6] A. Rizqiawan, E. Gamia, and P. A. Dahono, "Economic Aspect of Hybrid Renewable Energy System for Base Transceiver Station," in 2019 IEEE 13th International Conference on Telecommunication Systems, Services, and Applications (TSSA), 2019, pp. 102-107.

[7] R. R. Saedudin, R. A. Anugraha, and R. Eka, "The optimization of maintenance time and total site crew for Base Transceiver Station (BTS) maintenance using Reliability Centered Maintenance (RCM) and Life Cycle Cost (LCC)," in 2013 IEEE International Conference on Industrial Engineering and Engineering Management, 2013, no. Lcc, pp. 1304-1308.

[8] S. Kabir, M. S. Islam, M. Aminuzzaman, A. Ahmed, and M. R. H. Khan, "Renewable integrated Hybrid Power Management for Off Grid Base Transceiver Station (BTS): Microcontroller based," in 2015 International Conference on Electrical Engineering and Information Communication Technology (ICEEICT), 2015, no. May, pp. 1-4.

[9] D. Abidin, "A Hybrid Genetic - Differential Evolution Algorithm (HybGADE) for a Constrained Sequencing Problem," in 2018 International Conference on Artificial Intelligence and Data Processing (IDAP), 2018, pp. 1-6.

[10] D. Chaudhary, A. K. Tailor, V. P. Sharma, and S. Chaturvedi, "HyGADE: Hybrid of Genetic Algorithm and Differential Evolution Algorithm," in 2019 10th International Conference on Computing, Communication and Networking Technologies (ICCCNT), 2019, pp. 1-4.

[11] X. Zhou, H. Zhang, and L. Ma, "The influence of process parameters on the surface topography in diamond turning of freeform optics," 2010 Int. Conf. Mech. Autom. Control Eng. MACE2010, no. 50775099, pp. 3480-3483, 2010.

[12] L. O. Hall and D. B. Goldgof, "Convergence of the Single-Pass and Online Fuzzy C-Means Algorithms," IEEE Trans. Fuzzy Syst., vol. 19, no. 4, pp. 792-794, Aug. 2011.

[13] T. Celik and H. K. Lee, "Comments on "A Robust Fuzzy Local Information C-Means Clustering Algorithm," IEEE Trans. Image Process., vol. 22, no. 3, pp. 1258-1261, Mar. 2013.

[14] L. A. Zadeh, "Fuzzy Sets," Inf. Control, vol. 8, pp. 338-353, 1965.

[15] R. E. Bellman and L. A. Zadeh, "Decision-Making In A Fuzzy Environment Report No ERL-69-8 National Aeronautics And Space Administration," 1970.

[16] L. A. Zadeh, "The Concept of a Linguistic Variable and its Application to Approximate Reasoning," Inf. Sci. (Ny)., vol. 8,
1975.

[17] T. Tagaki and M. Sugeno, "Fuzzy Identification of System and its Application to Modeling and Control," IEEE Trans. Syst. Man Cybern., vol. 15, no. 1, pp. 116-132, 1985.

[18] E. H. Mamdani, M. S. Eng, D. Ph, and I. E. E. E. Mem, "Control \& Science Application of fuzzy algorithms for control of simple dynamic plant," vol. 121, no. 12, pp. 1585-1588, 1974.

[19] Z. Y. Zhao, M. Tomizuka, and S. Isaka, "Fuzzy Gain Scheduling of PID Controllers," IEEE Trans. Syst. Man Cybern., vol. 23, no. 5, pp. 1392-1398, 1993.

[20] C.-L. HWANG, Y.-J. LAI, and T.-Y. LIU, "A NEW APPROACH FOR MULTIPLE OBJECTIVE,” Comput. Ops Res. Vol. 20, vol. 20, no. 8, pp. 889-899, 1993.

[21] F. Radmehr and N. S. Gharneh, "Forecasting Method Based On High Order Fuzzy Time Series And Simulated Annealing Technique," South African J. Ind. Eng., vol. 23, no. 2, pp. 176190, 2012.

[22] B. S. Chissom and S. Qiang, "Practical Experiences with Modelling and Forecasting Time Series," in The Annual Meeting Of the Mid-South Educational Research Association, 1991.

[23] J. C. Bezdek, Pattern Recognition with Fuzzy Objective Function Algorithms. 1981.

[24] J. M. Haigh and R. G. Caringi, "Automation vs. human intervention: What is the best mix for optimum system performance? A case study," Int. J. Risk Assess. Manag., vol. 7, no. 5, pp. 708-721, 2007.

[25] M. Alata, M. Molhim, and A. Ramini, "Optimizing of Fuzzy CMeans Clustering Algorithm Using GA," World Acad. Sci. Eng. Technol., vol. 15, no. October 2016, pp. 224-229, 2008.

[26] O. M. d. Alia, R. Mandava, D. Ramachandram, and M. E. Aziz, "Harmony search-based cluster initialization for fuzzy C-means segmentation of MR images," IEEE Reg. 10 Аnпи. Int. Conf. Proceedings/TENCON, no. February, 2009.

[27] R. Siringoringo and J. Jamaluddin, "Peningkatan Performa Cluster Fuzzy C-Means pada Klastering Sentimen Menggunakan Particle Swarm Optimization," J. Teknol. Inf. dan Ilmu Komput., vol. 6, no. 4, p. 349, 2019.

[28] Y. Feng, H. Lu, W. Xie, H. Yin, and J. Bai, “An Improved Fuzzy C-Means Clustering Algorithm Based on Multi-chain Quantum Bee Colony Optimization," Wirel. Pers. Commun., vol. 102, no. 2, pp. 1421-1441, 2018.

[29] A. Mauludiyanto and Jiworeno, "Estimasi Zona Menara Baru Pada Komunikasi Selular Di Kabupaten Mojokerto menggunakan Geographic Information System (GIS)," in Seminar Nasional Teknologi Informasi dan Multimedia 2015, 2015, pp. 6-8.

[30] E. Jamil and S. Hameed, "STATCOM-Based Voltage Regulation in Grid Integrated Wind Farm under Variable Loading Conditions," pp. 0-5, 5093. 